\title{
Interventions in the political geographies of walls
}

\author{
Karen E. Till ${ }^{\mathrm{a}, *}$, Juanita Sundberg ${ }^{\mathrm{b}}$, Wendy Pullan ${ }^{\mathrm{c}}$, Charis Psaltis ${ }^{\mathrm{d}}$, Chara Makriyianni ${ }^{\mathrm{d}}$, \\ Rana Zincir Celal ${ }^{\mathrm{d}}$, Meltem Onurkan Samani ${ }^{\mathrm{d}}$, Lorraine Dowler $^{\mathrm{e}}$ \\ a Department of Geography, National University of Ireland Maynooth, Maynooth, County Kildare, Ireland \\ ${ }^{\mathrm{b}}$ Department of Geography, University of British Columbia, Vancouver, B.C., Canada \\ ${ }^{\mathrm{c}}$ Department of Architecture, University of Cambridge, Cambridge, United Kingdom \\ ${ }^{\mathrm{d}}$ Association for Historical Dialogue and Research, Home for Cooperation, 28 Marcou Dracou St, Nicosia 1102, Cyprus \\ ${ }^{\mathrm{e}}$ Departments of Geography and Women's Studies, Penn State University, University Park, PA 16802, USA
}

\author{
Keywords: \\ Walls \\ Borders \\ Jerusalem \\ Nicosia \\ Belfast \\ Berlin \\ US-Mexico border \\ State power \\ Resurgent sovereignty \\ Place-based sovereignty \\ Conflict infrastructures \\ Infrastructures of peace \\ Witnessing
}

\section{Walls, resurgent sovereignty and infrastructures of peace}

\section{Karen E. Till}

Walls are symbolic and material manifestations of political boundaries. This Intervention builds upon recent work in political geography that considers borders as sovereign sites of security as well as mobile places of encounter (Johnson et al., 2011; Jones, 2012; Mountz, 2011). Walls may fulfill divisive state agendas through "conflict infrastructures" as Wendy Pullan describes in her Intervention; at the same time they may be used by borderland inhabitants to create "infrastructures of peace" as Charis Psaltis, Chara Makriyianni, Rana Zincir Celal, and Meltem Onurkan Samani argue. Through our focus on walls, we pay attention to new forms of state power, such as "resurgent sovereignty" (Butler, 2006), but also to what Lorraine Dowler describes as "place-based sovereigns" and their embodied practices, such as acts of witnessing that Juanita Sundberg portrays.

Walls "are historically contingent and characterized by contextual features and power relations" (Paasi, 2011, p. 62). In past and

\footnotetext{
* Corresponding author. Tel.: +353 1708 3610; fax: +353 17083573.

E-mail address: karen.till@nuim.ie (K.E. Till).
}

present, walls have designated configurations of state power. The paradigmatic Cold War case is the Berlin Wall. Established in 1961, this state surveillance system - maintained through minefields, watchtowers, walls, "no man's lands", and checkpoints - ran 124 miles around three western sectors, and between East and West Berlin. This material infrastructure was a symbol of the communist "security blanket", identifying political differences between an "us" and "them", an East Bloc and West Bloc.

As state wall building has become more, rather than less, pronounced following the fall of the Berlin Wall in 1989, scholars have revisited literatures on borders, walls, and state power at multiple scales (Kaplan \& Häkli, 2002; Silberman, Till, \& Ward, 2012). Brown (2010) understands "new" walls as indicative of an era of post-Westphalian "waning sovereignty". Although walls still function symbolically and materially in ways similar to their historic counterparts, for Brown new walls are a state response to "the ungovernability by law and politics of many powers unleashed by globalization and late modern colonialization" (p. 24). The new global landscape of blockading is evidence of state-perceived threats from the transnational flows of the "political economy and religiously legitimated violence" (p. 23) that "lack political form or organization" and have no clear "subjective and coordinated intentionality" (p. 24). Brown argues that the new walls demonstrate that state borders are blurred, and divisions between "us" and "them" are no longer clear.

While the conflation of military, police, and civilian surveillance border tactics do indicate a change in the nature of state sovereignty, state borders have long been selectively porous. Does this "new" global landscape of walled states and cities indicate a "loss" of sovereignty in response to globalization as Brown argues? Butler's (2006) arguments about "resurgent sovereignty" offer a different understanding regarding the changing nature of state power and borders in recent years. Resurgent sovereignty is a strategy of governmentality that suspends and deploys the law "tactically and partially to suit the requirements of a state that seeks more and more to allocate sovereign power to its executive and administrative powers" (p. 55). Drawing upon Agamben, Butler notes that the sovereign exception, as an exercise of prerogative power, is used to limit the jurisdiction of law within and beyond state borders. Resurgent sovereignty seeks "to neutralize the rule of 
law in the name of security" (p. 67). When the state claims the right to suspend the law and disregard international accords, it extends its power to decide what humans are no longer eligible for basic human rights (including the right to life) in the spaces and times of its own choosing. The state of exception, now the norm, becomes the space-times of exception. While extra-territoriality is not new, Butler argues that the mechanisms used by the state to restructure "temporality itself" are novel: the "problem of terrorism is no longer a historically or geographically limited problem" (pp. 64$65)$. Further, resurgent sovereignty indicates a state desire "animated by an aggressive nostalgia that seeks to do away with the separation of powers" (p. 61).

The building of new walls and their effects can be understood as technologies of resurgent sovereignty. First, the suspension of the law to manage populations moves through the intra-territorial pathways of wall infrastructures. As Sundberg describes in her Intervention, a new type of U.S.-Mexico border region has been created that justifies the retrenchment of existing civil rights, a process that she describes as "walling up democracy". The authority given to the Department of Homeland Security by the U.S. Congress to waive existing laws - in order to prevent "terrorists" from traveling and "bolster" state border security - has produced a "constitution-free zone" within and beyond the U.S.-Mexico border. Her Intervention demonstrates how the wall works to produce a new kind of "zone of exception" within a state to deny its own citizens basic rights.

Second, wall "conflict infrastructures" work through the spacetimes of "strategic confusion" as Pullan describes for IsraelPalestine in her Intervention. The wall's political infrastructures date back to the period just following the 1967 war. They now tactically connect Israeli neighborhoods through settlement and transportation planning. Pullan argues that the spatial depth associated with strategic anti-/planning ensures that even if the wall were removed division would remain. A related process of "infradestructure" (Azoulay, 2011) has resulted in the destruction of Palestinian schools, hospitals, homes, and neighborhoods in the name of "national security".

The space-times of conflict infrastructure mean that even when border crossings in divided states become possible, facilitating contact across borders, and creating shared narratives and spaces remain pressing challenges. As Psaltis et al.'s Intervention describes, years after some checkpoints opened up along the Green Line in Nicosia in 2003, most residents continued to live in separate social spaces. In such a divided context, the establishment of a bicommunal Home for Co-operation (H4C) in 2011 has created a new "infrastructure for peace". Through "transformative knowledge", civil society transnational networks, and the material possibilities enabled through the borderlands, the H4C offers a safe space of encounter because of its "neutral" location in a demilitarized zone. In a system of states of exception, this model of an alternative "third space", created by and producing new epistemologies, meshworks and social imaginaries, also illustrates "a life in potentiality, a surprising and unanticipated life that has capacity to interrupt the border line" (Amoore, 2011, p. 64).

According to Jones (2012), while people may accept the existence of state borders, "at other times they continue to think and live in alternative configurations that maintain connections across, through, and around sovereign state territoriality" (p. 697). Dowler's Intervention about the historical and living actors in Belfast offers a rich set of examples of what Jones calls "spaces of refusal", including a local neighborhood "people's festival", feminist peace demonstrations, and political tourism practices. "Place-based sovereigns" can be locals, residents, or even tourists; they reject, ignore, or rework the behaviors required by states to create "doors" in physical boundaries intended to be solid. Their bodies, movements, and stories work beyond and through walls to enable scholars to see the possibilities of cohabitation rather than of division only.

Whereas physical walls may be the most obvious symbols of conflict infrastructures, these Interventions attempt to make the other space-times of walls more visible. Sundberg's emphasis on witnessing offers new understandings of how democracies create exclusionary zones of exception that 'wall up' civil rights and rights to shared environments. Pullan's map (Fig. 4) brings to view otherwise known, but not often visible, wall infrastructures that divide cities and peoples and may ultimately last even longer than a material boundary. At the same time, the legacies of division, including "no man's lands" and abandoned structures, may be used to create "infrastructures of peace" that may connect residents years after physical violence subsides as Psaltis et al. discuss below. Finally, as Dowler's Intervention highlights, because new and old doors may be kept open in walls by place-based sovereigns, these lived practices offer a different perspective into the ways that borders move.

\section{Delimiting democracy: witnessing along the US-Mexico borderlands}

\section{Juanita Sundberg}

In 2006, former U.S. President George W. Bush signed the Secure Fence Act, mandating the construction of 850-miles of fencing along the 1954-mile boundary dividing the U.S. from Mexico. The vociferous and active opposition to the construction of border walls in south Texas drew me to the Lower Rio Grande Valley - homeland of border studies scholar Gloria Anzaldúa - in the hot summer months of 2008. Together with members of No Border Wall, a grassroots coalition organized to articulate dissent in the valley, I set out to witness the implementation of the Secure Fence Act. Though initially drawn by debates about identity and national security prominent in border studies (Ackleson, 1999; Kaplan \& Häkli, 2002; Meinhof, 2002; Paasi, 1996), bearing witness to the daily, placebased practices involved in walling the border revealed profound concerns about democratic process. I argue that wall building in the southern U.S. is implicated in walling up democracy. The suspension of law at the edges of the nation's territory has numerous implications that have yet to be fully considered by political geographers.

I make this argument at a moment of renewed interest in sovereignty, in part spurred by studies inspired by Agamben's work on sovereign power and state violence (Gregory, 2006; Jones, 2009). While Brown (2010) suggests that the proliferation of border walls around the world indicates the waning of state sovereignty in the face of globalization and powerful non-state actors, other scholars emphasize the continuing and, indeed, increasing power of states to draw boundaries between inside and outside, legal and illegal, as well as "politically qualified life and merely existent life" (Gregory, 2006, p. 406). While much of this literature has focused on the U.S. government's so-called war on terror (Butler, 2006; Gregory, 2009), I draw attention to legislation that produces the U.S. borderlands as a space of exception in the name of building border infrastructure. By weaving together narratives drawn from witnessing the construction of the border wall in the Rio Grande Valley, I capture the daily excursions of No Border Wall activists to document the progress of construction. The concept of witnessing honors Anzaldúa's (1987) evocative and deeply personal writing about identity and life in the borderlands. No Border Wall witnessing practices are meant to inform a geographically distanced public about the actual practices of wall building; I further their practice by suggesting that the judicial and legislative processes meant to protect citizens are instead used strategically to wall up democracy. 
Creating divisions between people is a walling strategy. The Secure Fence Act of 2006 identified three priority areas in Texas where at "least two layers of reinforced fencing" should be built. South Texans immediately organized to contest the wall and its underlying supposition that the Río Bravo/Rio Grande River forms a boundary between different peoples (No Border Wall, n.d.). "The river is what connects, not divides us" was a refrain I heard repeatedly in city council meetings, protests, and individual interviews. "No wall between amigos" was another (Fig. 1).

The Texas Border Coalition, a group of mayors, county judges, and business leaders from El Paso to Brownsville openly opposed what Laredo's then mayor called the "wall of shame" (McLemore, 2007). In a 2008 city commissioners' debate about a proposed border wall on the southern banks of the river in Brownsville, Mayor Ahumada told a packed city hall he was very proud of his binational heritage and would be unable to choose between his Mexican-born mother or American-born father: "I couldn't make that decision and nobody should have to," he said.

At a 2008 congressional field hearing in Brownsville, valley residents conveyed their fears about how a border wall would destroy their bi-national way of life. A local landowner and activist told officials: "It isn't really a border to most of us who live down here" (cited in Sieff, 2008). Angered by her comments, Colorado Congressman Tom Tancredo criticized what he called landowners' "multiculturalist attitude toward borders", suggesting: "If you don't like the idea (of a fence), maybe you should consider building the fence around the northern part of your city" (Ibid). Tancredo's statement is a performance of walling: he suggests that predominantly Latino/a south Texas communities do not belong to the nation and therefore should be physically relocated outside national territory. But Tancredo also is saying that dissent threatens the nation-state and dissenters should be walled off.

These moments demonstrate the importance of bi-national identifications for valley residents and resonate with existing research on boundaries as points of connection as well as division (Newman, 2006). And yet Tancredo's sinister comments also draw attention to the ways in which the construction of U.S. border walls serves to demarcate exclusion and delimit democratic process.

Wall building also proceeds by waiving the law. In meetings with U.S. Department of Homeland Security (USDHS) Secretary Michael Chertoff in early 2007, Texas leaders were told they would be consulted if and when any fencing was planned for the Texas

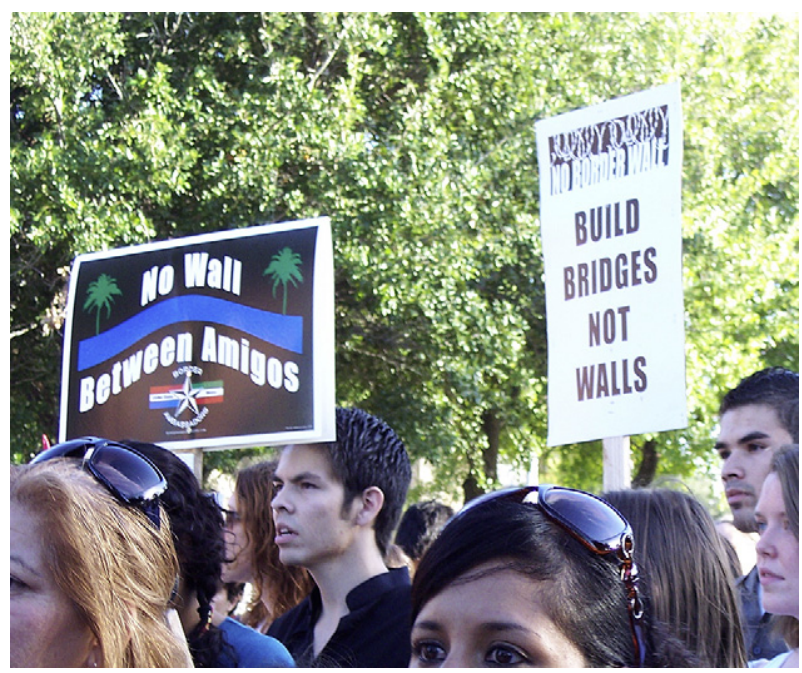

Fig. 1. The Río Bravo/Rio Grande river as a symbol of unity not division: No Border Wall protest, Texas, 2008. Photo by Juanita Sundberg. border (Whitaker, 2007). However, a confidential memo from USDHS dated 20 April 2007 addressed "Dear Texas Homeland Security Partner" was leaked to the media along with a map detailing over 153 miles of fencing planned for Texas (McLemore, 2007; Osborne, 2007). Although federal officials claimed the map was merely a "starting point", Texas leaders were stunned (McLemore, 2007). In the words of a county judge, "We felt like we'd been hit below the belt...They tell us we'll be consulted, then we find they've carved up the border and were already going out for bids" (cited in McLemore, 2007; see also Cortez, 2008).

Amidst a great deal of uncertainty as to where and how walls would be built in Texas, USDHS initiated protocols established by the National Environmental Policy Act (NEPA) for seventy miles of fencing in the Lower Rio Grande Valley. The NEPA is federally mandated to ensure citizen participation, consider environmental sustainability and environmental justice, provide safe and healthful surroundings, and preserve national heritage sites. Throughout the NEPA process, steadfast opposition by local federal and state officials as well as grassroots groups like No Border Wall delayed construction of walls in south Texas. Then, on April Fool's Day 2008, USDHS Secretary Chertoff invoked his authority "to waive any legal requirements that [he], in [his] sole discretion, determine[d] necessary to ensure expeditious construction of this much-needed border infrastructure" (USDHS, 2008).

The U.S. Congress granted this authority to the DHS secretary when it passed the REAL ID Act in 2005. Republican Congressman James Sensenbrenner claimed the act "is aimed at preventing another 9/11-type attack by disrupting terrorist travel and bolstering our border security" (USHRCJ, 2005). During congressional debate, Democratic Congresswoman Sheila Jackson-Lee shifted attention to the unprecedented authority the act would grant to DHS (USHRCR, 2005, H459):

To my knowledge, a waiver this broad is unprecedented. It would waive all laws, including laws protecting civil rights; laws protecting the health and safety of workers; laws, such as the Davis-Bacon Act, which are intended to ensure that construction workers on federally-funded projects are paid the prevailing wage; environmental laws; and laws respecting sacred burial grounds.

Jackson-Lee's comments point to the unprecedented concentration of power given to the executive branch by the REAL ID Act's waver provision. The REAL ID Act only allows for redress on the grounds the constitution has been violated and only at the level of federal district court (Bowers, 2010). Cases put forward by environmental organizations challenging the constitutionality of Chertoff's waivers have been dismissed in court and the Supreme Court has refused to hear any petitions.

The waiver provision has its roots in thwarted attempts to complete a triple fencing project in San Diego, California in 2004. Completion of the San Diego wall had continually come up against environmental regulations, which denied permits to plow through the Tijuana River National Estuarine Research and Reserve. The waiver authority granted to USDHS in 2005 allowed Chertoff to move forward and complete the fence by ensuring that environmental organizations would be unable to use the judicial system to force the government to comply with its own mandates. In short, the waiver provision walled off the justice system.

When Chertoff invoked his waiver authority, he waived thirtysix federal laws, including the NEPA, Clean Water Act, Clean Air Act, Endangered Species Act, Native American Graves Protection and Repatriation Act, and Safe Drinking Water Act. Many of these laws are the result of demands made by social movements. In waiving NEPA, Chertoff also stripped valley residents of their political rights to publically consider what it would mean to live 
with a border wall. What about property owners whose land would end up south of the wall? Or the Lipan-Apache community members whose land was granted by the Spanish Crown in the 1770s; would their land be seized to build the wall? How would farmers get to their fields, if located south of the wall? Or, what of the ocelots - small felines - who need to cross the Rio Grande in search of mates? Chertoff waived away these questions on that historic day, leaving valley residents with no recourse and no legal protections.

After the waivers, USDHS to moved forward quickly with wall construction. In turn, No Border Wall participants initiated the practice of witnessing the progress (Fig. 2). We watched as construction crews deconstructed levees in the Lower Rio Grande River flood control system, leaving valley residents vulnerable to flooding in the middle of hurricane season; documented construction sludge being pumped into federally protected stopover habitat for migrating waterfowl and nesting habitat for resident birds; laughed, when we located cat holes in the steel fencing that allowed ocelots to move through the landscape without compromising national security.

The waiver authorization is no longer considered a temporary strategy. Republicans have introduced two Congressional bills that would make the waiver of laws a permanent feature of the U.S. borderlands. The National Security and Federal Lands Protection Act, which the House of Representatives passed in June 2012, will make sixteen of the thirty-six laws included in Chertoff's 2008 waiver permanent within all lands under the jurisdiction of the Departments of the Interior and Agriculture which lay within 100miles of U.S. land borders. In a somewhat similar tactic, the proposed Border Security Enforcement Act of 2011 would prevent the Departments of the Interior (DOI) and Agriculture from

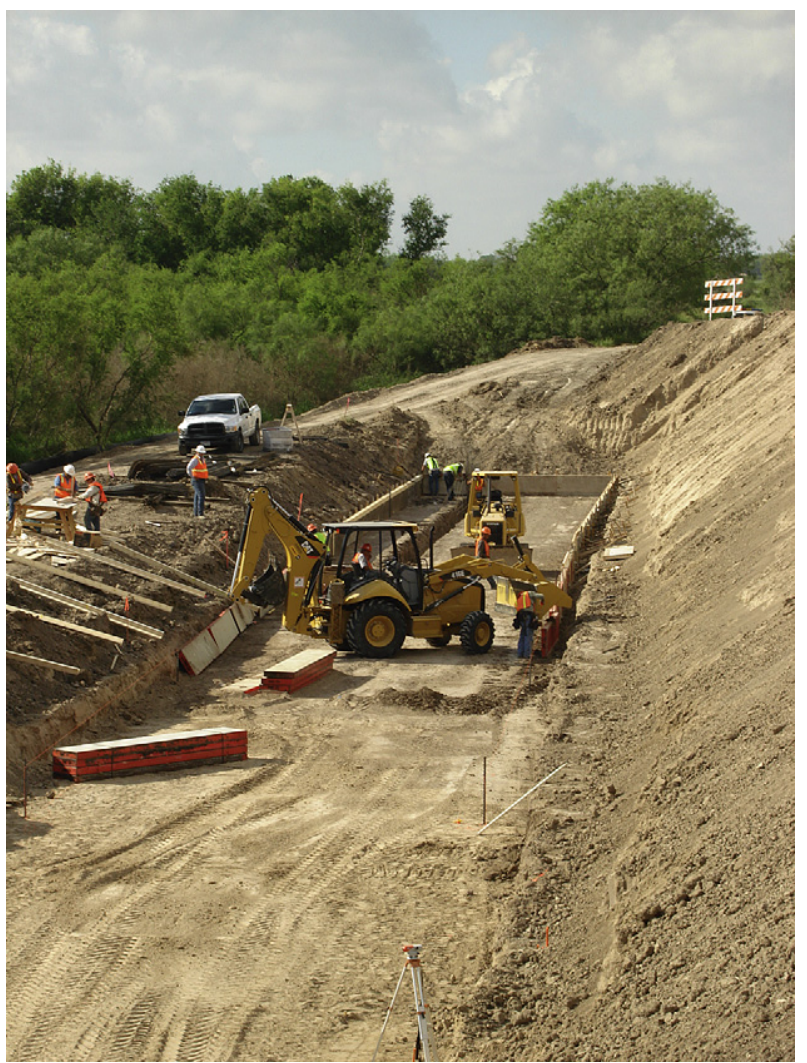

Fig. 2. Witnessing levee border wall construction at Monterrey Banco National Wildlife Refuge, 2008. Photo courtesy of Wayne Bartholomew. enforcing laws in federally designated areas within 150 -miles of the political boundary, if and when the Department of Homeland Security deems DOI laws to be in conflict with national security agendas (set by USDHS or the Executive Office).

These proposed bills legitimize and further entrench the notion of the U.S. borderlands as a "constitution-free zone", a term that the American Civil Liberties Union (ACLU) (2008) uses to refer to a 100mile strip around the perimeter of the U.S.A. wherein Customs and Border Protection assumes extraordinary (and unconstitutional) powers to arbitrarily stop and search people. The ACLU has calculated that two-thirds of the U.S. population (or 197.4 million people according to 2007 census data) lives within this constitution-free zone.

A Texas Legal Aid attorney used the term constitution-free zone to refer to the state of democracy in the Rio Grande Valley (interview with author, 2008). The widespread waiver power granted to the executive branch essentially circumvents the checks and balances built into the democratic system. As the director for a small wildlife sanctuary in the valley told me in an interview in 2008: "Congress may as well suspend our right to vote here in the Valley" because "the heart of the democratic process has been cut out" with USDHS wall building. He explained:

If our elected officials cannot expect their legislative actions to be respected by the executive branch of government and our ability to challenge that is essentially limited to the capricious benevolence of the Supreme Court, we've pretty much thrown out the democratic process and the rule of law all in one fell swoop.

In sum, residents (human and nonhuman) of the U.S. borderlands not only live in a constitution-free zone where constitutional guarantees are suspended, but the REAL ID Act waiver provision also means that basic rights such as clean air and water may be waived at the discretion of the executive branch.

Witnessing these daily practices and contestations of wall building in south Texas pushed me to consider the implications for democracy in the U.S. for border studies. The legal mechanisms used to expedite the construction of U.S. border walls expanded the executive branch's capacity to suspend the law in the name of national security (Bowers, 2010). In the process, the sovereign power of the executive branch is strengthened in ways that neutralize the legislative and judicial branches. In contrast to Brown's argument, the process of building border walls in the U.S. suggests a resurgence of sovereignty (Butler, 2006). Such transformations in sovereignty require renewed attention to boundary making as a technique of power used to reconfigure the state and its relationship to citizens within the space of the nation.

\section{Strategic confusion: icons and infrastructures of conflict in Israel-Palestine}

\section{Wendy Pullan}

Since the first sections of the wall were built in Palestine in 2002, the world's attention has been galvanized by this structure. Snaking across the landscape, breached by protestors, and targeted by conflict tourists, the wall has figured regularly in the media as the embodiment of the Israeli-Palestinian conflict. At a time when states increasingly resort to building walls instead of finding more reasonable means for dealing with disputes, this particular example has become the most famous since the demise of its counterpart in Berlin in 1989.

The wall has become subject to its own prominent image. In situ, the wall has been the setting for art installations, films, tourism, and activist events: by painting on its surface, Banksy and the Battistas have consolidated their fame, much to the delight of 
international aficionados if not always the locals. Both tourists and Palestinians proclaim their repugnance of it or simply vent their frustrations in paintings and graffiti. Although it is witnessed in the flesh by Palestinians, settlers, and activists, most Israelis inside Israel experience the structure as a media image just like the rest of the world. As such it is remote, reified, perhaps a little unreal, quick to provoke anger, or confidence, and just as easy to forget.

More than any commentary on it, the structure of the wall can take on its own aesthetic quality, potently sculptural in the stark light and shade of the region. Its own iconicity is central to the attraction, and in the combination of beauty and horror, it is tempting to see it as a reinvention of the Sublime, fit for twentyfirst century savagery. The machine aesthetic has been rampant in the West for about a century; infrastructures like bridges, cranes, causeways, motorways - and walls - are used to convey speed, strength, energy, and fashion, and understood to be part of Modernism's visual legacy of transparent functionality and unabated power. But as with many structures that are more complicated than the image they initially project, the wall detracts deceptively from other more important problems, especially longterm prospects for peace in the region.

Israel continues to claim that the barrier is for security; the Palestinians have regarded it as a land grab. In the years since its inception, the structure is more clearly part of a larger program to dismantle Palestinian East Jerusalem, encourage emigration and generally restrict Palestine as a state (Dolphin, 2006; Dumper \& Pullan, 2010, pp. 1-16). A conflict infrastructure has been developed and maintained that includes Israeli civilian settlements and

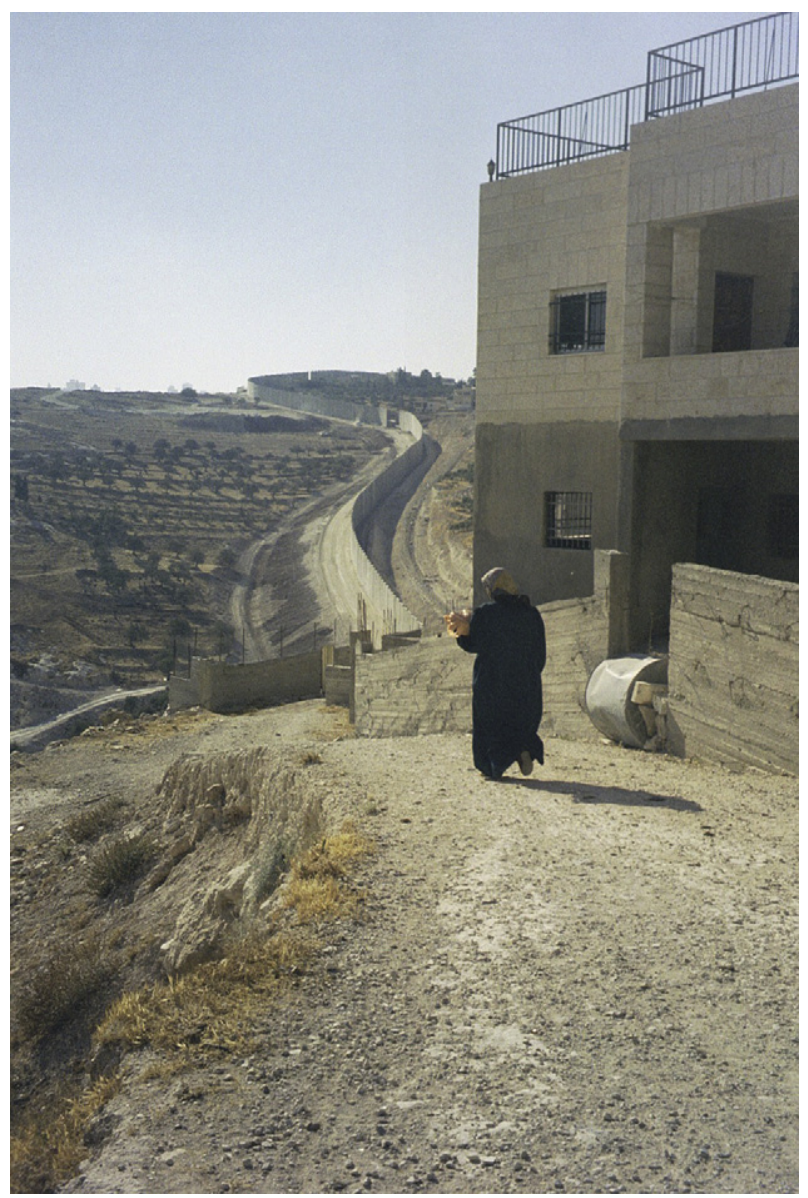

Fig. 3. The separation barrier at Jerusalem's Abu Dis neighborhood, 2008: the political aesthetics of a contested landscape. Photo courtesy of Conflict in Cities. a segregated road network. The wall is simply the most visible part of this infrastructure (Fig. 3). Built unilaterally by the Israelis on Palestinian land, the separation barrier is constructed in nonpopulated areas as a 160-330 foot-wide ditch and fence system, enhanced with cameras, watch towers, razor wire, raked sand, and a patrol road to allow monitoring through it. In cities, it is a solid nineteen to twenty-six feet concrete wall with towers and gates to prevent sniping in civilian crowds (Israel Ministry of Defense, 2012). The wall appears permanent, but is actually are made up of prefabricated modules that have been dropped into place by crane without deep foundations; in the same manner that they have been laid, they can also be extracted. While not to diminish the present distress caused to Palestinians, or the unpleasant tendency of such "temporary" structures to endure, it is important to realize that, as a structure, the wall can come down.

Much of the disruption and suffering caused by the long term occupation in Palestine has intensified with the Israeli policy of closure; the wall and checkpoints aid its enforcement, but it is all part of a historical process of occupation and control in the West Bank that developed in the immediate period after the 1967 war. Broad infrastructures constitute it: water, electricity, police and military control, segregated roads, and most of all, the civilian enclaves restricted to Jewish inhabitants. In the long term the settlements, more than the military, have made the occupation, and they are bound by a complex interdependency of all of the infrastructural systems. For the settlements, the infrastructures are their "elixir of life...the secret of their power" (Zertal \& Eldar, 2007, p. xv), without which they could not exist.

Many of the settlements are full-scale suburban towns, with schools, commercial centers, community halls, and parks. Far from a pioneering ethos of a few rough caravans on a hilltop, it is their ambience of middle-class contentment that strikes one: the possibilities for evacuation are remote. They are permanent, spoilers for any hope of a long term and just solution. The map of Jerusalem is particularly revealing (Fig. 4), showing settlements that house about half of the West Bank Jewish population. Deep into Palestinian territory is Maale Adumim, with about 40,000 inhabitants, but more disturbingly, E1, the "settlement in waiting", stands between Maale Adumim and Jerusalem. As a designated settlement, the E1 area has undergone massive destruction to the existing semi-arid landscape in order to equip it with infrastructure for up to 25,000 people. Divided carriageways, roundabouts, and bridges wait for vehicles; electricity pylons march out into the desert; only the buildings (and settlers) are missing due to a freeze ordered by the US government. If realized, the settlement will complete the Israeli corridor from Maale Adumim through to Jerusalem and divide the northern West Bank from the southern, destroying the possibilities of a viable Palestinian state (Arieli, 2008).

Across the Jerusalem map, settlements have been built amongst the Palestinian villages and suburbs, hemming them in and preventing their ability to grow, and creating their own, Israeli, spatial contiguity. At the same time, no local roads connect Palestinian and Israeli neighborhoods; the two peoples gaze at each other across the valleys, but physical access is denied. It is a bizarre approach to planning, using one civilian neighborhood to scupper another. Nearly 30 years ago the initiative was explained to the Jerusalem Committee, Israeli Mayor Teddy Kollek's international advisory body, as a molding of the city "into a greater Jerusalem that is altering the physical and political character of the region" (Kroyanker, 1982, p. 27); today we see the results.

Throughout the West Bank, from major highways to minor connections, a segregated road system exists. Modern, high-speed motorways, completely lit at night, have been built to connect the settlements to each other and to the major cities inside Israel. Most 

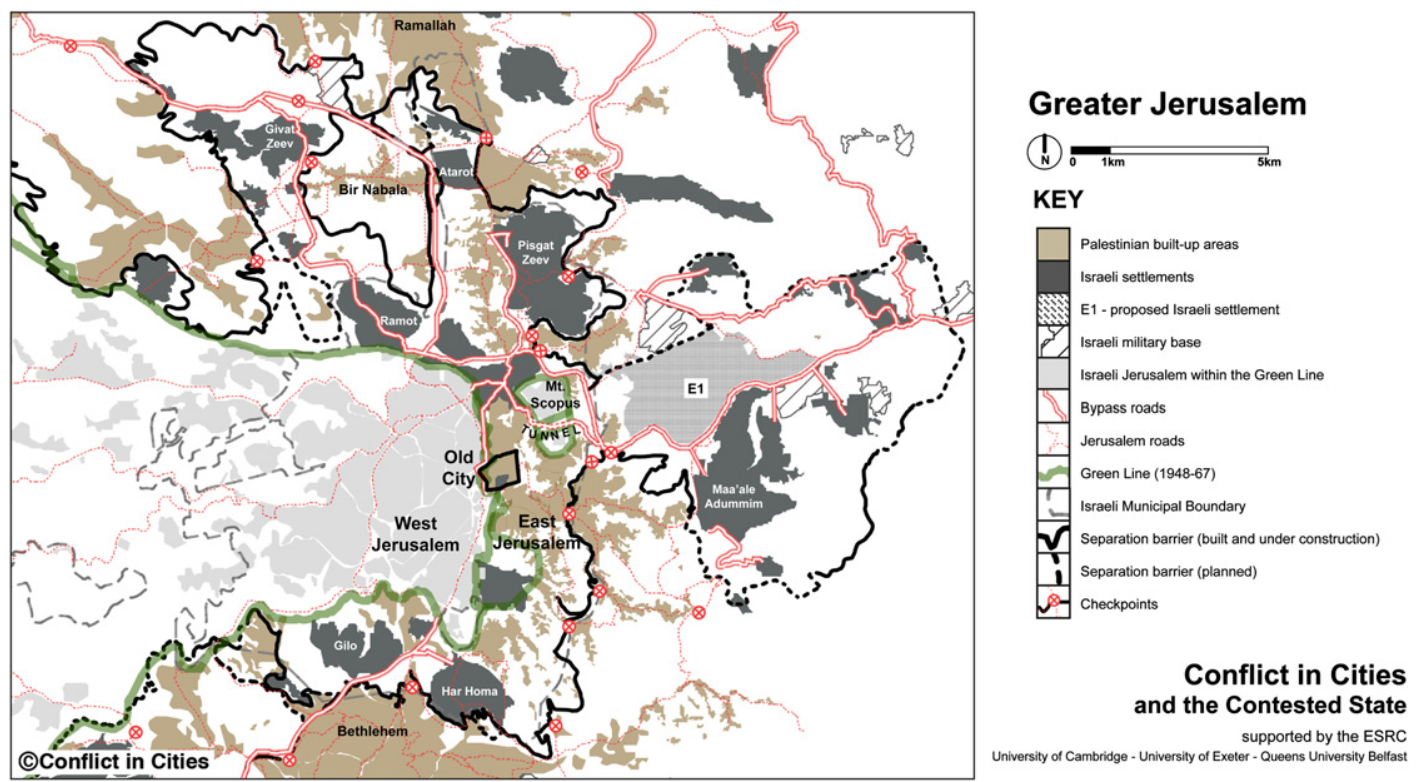

Fig. 4. The conflict infrastructures of greater Jerusalem: wall, settlements, bypass roads. Map produced by Conflict in Cities.

critically, they have been constructed to avoid areas of Palestinian habitation. The bypass roads skirt and surpass the old existing road system that has been left for the Palestinians; restricted by checkpoints and forbidden roads, the population is regularly forced to choose slower, more difficult routes, if, in the end, any access is available to them. The wall has allowed Israel to take approximately 15-20\% of Palestinian land, but restricted access increases this almost threefold: according to a World Bank report (2007), the segregated road system denies access to $50 \%$ of the West Bank to Palestinians. Converting a transport system, that under the British and Jordanians was constructed to follow the natural and built topography and connect all areas of population, to one that is formed by political expediencies to separate certain groups of population, has unsurprisingly resulted in a tangled confusion, relieved only by the liberal use of expensive causeways, bridges, and tunnels. Moreover, none of the restrictions, nor the overall road policy, has been stated or legislated; they are a "collection of undeclared measures that together form a single, undeclared policy" (Lein, 2004, p. 35), enforced ad hoc by soldiers as they see fit. The bypass roads have helped to make the spacious homes and gardens of the settlements convenient and secure for Israelis, whose domestic opportunism may be stronger than their political ideologies. But perhaps most worryingly, history shows that major road systems are usually the most enduring and powerful human artifacts in any landscape. Roman roads still order their respective terrain, and so will the segregated transport systems continue to dominate the West Bank topography, configuring it well into the future, long after the demise of the wall. B'Tselem, the Israeli Information Center for Human Rights in the Occupied Territories, states that "the vast majority of the roads that Israel has built in the West Bank is to strengthen its control over the land" (cited in Lein, 2004, p. 9). Mobility, and its patterns of restriction and confiscation, has become key to the spatial structure of the occupation (Pullan, 2007).

In the West Bank, commonsense planning for everyday life has been sabotaged in favor of complex infrastructural systems that support the occupation. As Minister of Housing in 1992, Ariel Sharon boasted that his aim was to scatter settlements and roads to create a "logic of disorder", and in this way prevent a tidy relinquishing of territory and return to the Green Line (Zertal \& Eldar, 2007, p. 100). This has now become an extensive strategy, dependent upon a number of Kafkaesque scenarios which help to promote the status and well-being of one national group over another; in effect, the West Bank has been recreated as an absurd stage upon which only the settlers are party to the play and its props. Planning is regularly countered by anti-planning to form a state of strategic confusion. It is probably worth noting that such a system is promulgated by a nation that has never had officially recognized borders, and has always used such fluid and uncertain conditions to its own advantage; even before the 1967 war, proposals for a security fence were rejected precisely because such an installation might confirm inconvenient or undesired political facts (Segev, 2007, pp. 206-207). More recently, we see the same policy of strategic confusion: in the 1990s, the Oslo peace process was sold with a slogan that promoted the two state solution, "we are here and they are there". But subsequent facts on the ground have been made to resist such clear divisions, and the Israeli Minister of Public Security (later Minister of National Infrastructures), Uzi Landau, claimed: "they are there, but we are here, and there as well" (cited in Foundation for Middle East Peace, 2002).

The ambivalent nature of borders (Johnson et al., 2011) is conducive to supporting strategic confusion. At the same time, a relatively silent conflict infrastructural program functions effectively in the background, as planned and implemented by a sovereign state. The wall appears as a hard separation and, in keeping with the key characteristics of iconic structures (Sklair, 2011), it remains bold and easy to recognize. With this image comes the assumption that the wall alone has substantially altered the terms of the occupation. Yet, the conjecture is mostly subterfuge, for the separation barrier is just one part of a long-term system. After all, this massively imposing structure divides only Palestinians from each other. Most significantly, the wall, which seems so well-defined in the image it projects, masks utterly confusing and deceptive conditions on the ground; together they are two sides of the same coin. As the system of strategic confusion in total becomes increasingly more entrenched, it should be attracting attention. For without properly addressing the whole 
conflict infrastructure, the demolition of the wall will not make the required critical difference.

\section{From intractable conflict to transformative knowledge: the Home for Co-operation in Cyprus}

\section{Charis Psaltis, Chara Makriyianni, Rana Zincir Celal, Meltem Onurkan Samani}

On 6 May 2011, near an open checkpoint along the 180-km patrolled United Nations (UN) Buffer Zone of Cyprus, a new political "third space" was launched. Leaders of Greek Cypriot and Turkish Cypriot communities, with the bicommunal grassroots initiative Association for Historical Dialogue and Research (AHDR), inaugurated the Home for Co-operation (H4C), an "infrastructure of peace" intended to turn a "dead zone into a zone of co-operation" (Makriyianni \& Onurkan Samani, 2011). Fig. 5 illustrates more than a celebration of political "neutrality" at a site of former division: it depicts an initiative that results from the states of exception that constitute Cyprus and the spatial practices of Cypriots who seek to overcome the legacies of a violent and costly "intractable conflict" (Bar-Tal \& Teichman, 2005; Kriesberg, 1998). The establishment of the $\mathrm{H} 4 \mathrm{C}$ offers a model for scholars and activists in other divided contexts in at least three ways: by challenging states of exception, dismantling division through transformative knowledge, and creating safe spaces of encounter.

First, internationally condoned systems of states of exception need to be identified as unhealthy for any democracy. States of exception support each other and become normalized over time; in Cyprus, such a system has prevented resolution to conflict and division at multiple scales (Constantinou, 2008). In 1960, the fledgling democratic state of Cyprus was created following agreements between Greece, Turkey, and the UK, rather than from the will of Cypriots. After 1964, the Republic of Cyprus became a Greek Cypriot-run state and many Turkish Cypriot people were displaced. After 1974, the Turkish army forced massive displacements of Greek Cypriots, which was accompanied by the suspension of property rights for many people under the suspension of law as part of the "doctrine of necessity" in the Republic of Cyprus (Trimikliniotis, 2010). The UK military bases in Cyprus are legally not part of the EU or the UK, but are considered "sovereign". The establishment of the Turkish Republic of Northern Cyprus (TRNC) in 1983, a selfdeclared state internationally recognized only by Turkey, is another state of exception. Finally, the Buffer Zone/Green Line area

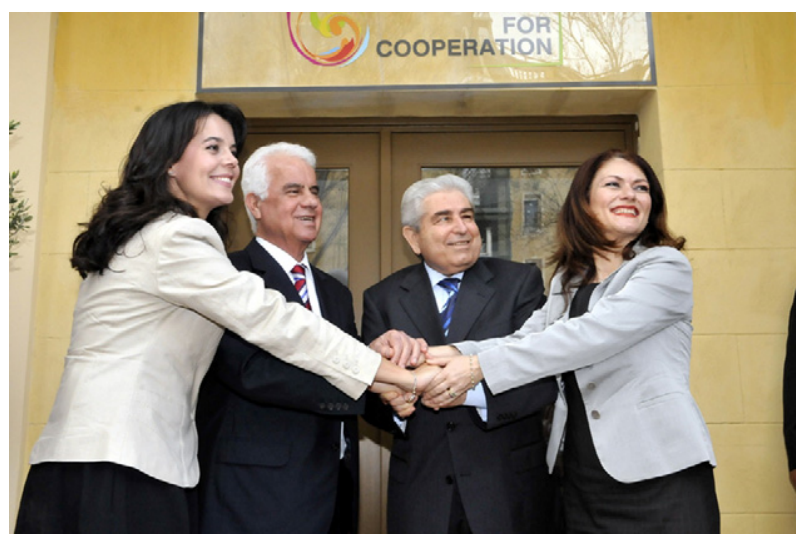

Fig. 5. Home for Co-operation inauguration with Dr. Chara Makriyianni, Association for Historical Dialogue and Research (AHDR) President; Turkish Cypriot leader Dr. Derviş Eroğlu; Greek Cypriot leader Dr. Dimitris Christofias; Dr. Meltem Onurkan Samani, AHDR Vice-President. Nicosia, Cyprus, 6 May 2011. Photo courtesy of AHDR. is controlled by the UN and marks their longest peacekeeping mission (UNFICYP, 2012). The Green Line reinforced existing political barriers within the walls of old Nicosia - along the fence that appeared during the 1955-1959 National Organization of Cypriot Fighters' struggle for union with Greece - rather than diffuse conflict. In the context of recent international negotiations over the island's status that continue to result in political stalemates, one wonders if this "peacekeeping measure" does more to perpetuate the status quo than to create possibilities for peace.

Conflicts are always physical and symbolic, transmitted across generations. Through time, citizens become accustomed to different societies whereby social representations of the Other reinforce fear, prejudice and, eventually, mistrust. This is true even after physical borders become penetrable, such as when movement was permitted at several crossings along the Green Line in 2003. Indeed, in response to checkpoint openings, a "resurgent sovereignty" (Butler, 2006) emerged when the Republic of Cyprus joined the EU as a Greek Cypriot run state. Greek Cypriot nationalist and communitarian/patriotic positions often argue that the checkpoints should close again because the movement of people to the north "supports the Turkish occupation" financially and ethically (cited in Psaltis, 2011). Intergroup contact between members of the two communities was strategically moralized by the 2003-2008 Greek Cypriot leadership (Demetriou, 2007), resulting in the reduction of crossings to the north by Greek Cypriots. Similar calls by the Turkish Cypriot administration to support only Turkish Cypriot financial institutions further inhibit the possibilities of trade and shared economic markets.

Claims related to displacement, restrictions on political identity through aggressive discourses, and the ongoing presence of military personnel demonstrate that longer-standing forms of intractable conflict continue to be part of everyday life for most Cypriots, including in places that one might expect alternatives to exist, such as formerly mixed villages (Lytras \& Psaltis, 2011) or in educational institutions (Psaltis, Lytras, \& Costache, 2011). Such examples point to the underlying material, political, and symbolic threats that stem from the possibility of upsetting a "normal" system based upon states of exception. Multiple generations remain alienated from life on the other side of the divide and create survival mechanisms to navigate segregated spaces (Constantinou, 2008). Nationalist narratives, and international and "sovereign" systems of exception hinder the cognitive and moral development of younger generations by suppressing social relations of mutual respect that are needed for the construction of knowledge and critical thinking (Psaltis, Duveen, \& Perret-Clermont, 2009).

Second, division and isolation must be dismantled simultaneously through what the AHDR calls "transformative knowledge". Existing official narratives and representations of space that alienate members of all communities must be identified and deconstructed. For example, distinct ideological positions about resolving "the Cyprus problem" orient the social psychological subject in the past, present, and future (Psaltis, 2011). Greek and Turkish Cypriot nationalisms are supported by historical narratives of continuity with the Greek and Turkish nations respectively; national spatial imaginaries depict Cyprus as part of the map of Greece or Turkey (Papadakis, 2008), or, for the latter, as divided with the northern part of the island (colored red on maps to refer to Turkey). After 1974, whereas Turkish Cypriot nationalists continued to aspire toward taksim (separation and possible union with Turkey), Greek Cypriots reoriented their policies toward the reunification of Cyprus, abandoning enosis (union with Greece). New forms of subjectivation appeared. A banal Greek Cypriot national identity (after Billig, 1995) projects communal identification to the superordinate category of "Cypriot". Not long ago, the cover of school exercise books was a bleeding Cyprus injured by the 
barbed wires of the UN Buffer Zone and the occupation of Turkish troops - an image familiar to a whole generation of Greek Cypriots. A new Turkish Cypriot identity known as "Kibrisli Turk" has also emerged that overidentifies with the TRNC to assert an identity of being neither simply Turkish nor Cypriot.

In contrast, when ideological and spatial routines that reinforce division are deconstructed, creating safe spaces of exchange can be explored. This is the third process needed to create infrastructures of peace. Human rights groups and civil society organizations have led the way in creating neutral spaces of encounter in at least two ways: by working at multiple scales to overcome division, and by using the gaps and inconsistencies of "borders" for peaceful purposes.

From 1964 to 2003, bi-communal peace initiatives included island- and diaspora-based Turkish and Greek Cypriots, academics, and diplomats, all of whom were committed to conflict resolution (Broome, 1998; Hadjipavlou-Trigeorgis, 1993). NGOs, peace research institutes, and private initiatives acted with the funding support of national governments, the EU, or the UN. International agencies, such as the United Nations Development Program (UNDP), the International Bank for Reconstruction and Development (IBRD), and the World Health Organization (WHO), also facilitated bicommunal meetings in pursuit of the objectives of their mandates (Hocknell, 2001; Loizos, 2006). The 2003 openings offered Cypriots the possibility to work more freely on bi- and intercommunal endeavors; projects now exist related to gender equality, environmentalism, and historical education.

Joint projects across the divide, however, are still viewed with suspicion, are often considered inconsequential, and are difficult to fund. Limited social infrastructures, with restrictions on movement, prevent broader political support and public interest. Civil society initiatives thus have strategically developed contacts at multiple scales to establish temporary or semi-permanent alternative spaces of encounter. For example, the AHDR, established by historians, educators, social psychologists, and activists in 2003, uses its networks on both sides of the divide and internationally to offer inter-communal history teaching training programs, provide alternative educational materials, and create dialogue-based knowledge constructed through exchanges between Greek, Turkish, Armenian, Maronite, and Latini/Latin (of Roman-Catholic background) Cypriot citizens. AHDR projects are organized both independently and with the support of local and European organizations, including the Council of Europe, EUROCLIO and teacher trade unions across the divide. Similarly, other organizations obtain support from the Civil Affairs Section of the UN Peace Keeping Mission in Cyprus (UNFICYP) and the UN Development Program. The UNFICYP also encourages civilian uses of the Buffer Zone through agricultural work, maintenance of public utilities and communications, and the construction of commercial and residential buildings.

The spatial gaps in borders, including so-called open borders, have also been used strategically by human rights organizations and NGOs. In Nicosia, individuals involved in civil society activities after 2003 physically moved along a main street that connected north and south, and went through venues in border zones operated by international actors: the UN at the Ledra Palace Hotel, the US at the Fulbright Center, and Germany at the Goethe Institute. The AHDR realized this emerging "non-terrain", in part created by what Dowler describes in her Intervention as "open doors in walls", could offer a setting for Cypriots to explore diverse alternatives and models in education, the arts, community programming, and the media. However, purchasing and refurbishing a deserted building in the former "no man's land", and transforming it into the "home" of a new radical imaginary - even with open doors - required "scale negotiating" strategies. To maintain the symbolic neutrality of a "third space", AHDR sought financial support from funders across the divide and from international actors (embassies of foreign countries supporting rapprochement; teacher trade unions pursuing bi-communal work). The resources needed for the project also required EEA financial mechanisms to fund and channel international grants through the planning bureaucracies of the Republic of Cyprus. The AHDR was thus able to acquire a building in 2010 through a multi-scaled network of Cypriot activists, international political and financial donors, the UNDP, and private individuals and organizations.

The possibility for such spatial practices to congeal was also a result of the very tangible legacies of a divided city. This house stood empty for more than 30 years in the UN Buffer Zone. Originally constructed in the early 1950s by the Armenian Mangoian Brothers and once surrounded by historic monuments, including French Lusignian and Venetian walls, Islamic structures, and an Armenian monastery and cemetery, this building stood in a neighborhood with Armenian, Greek, and Turkish Cypriots homes and enterprises, including Cyprus's leading hotel, the "Ledra Palace" (Epaminondas, 2011). By the 1960s, cohabitation across this main artery of the city was replaced by barricades and security forces, creating abandoned buildings and gardens (Fig. 6).

The $\mathrm{H} 4 \mathrm{C}$ concentrates symbolic meanings of co-operation by putting infrastructures of peace into practice. The geographical and historical context of the $\mathrm{H} 4 \mathrm{C}-\mathrm{a}$ historical multi-communal, multi-functional area where commercial and residential life was tightly interwoven, located in a buffer zone of intractable conflict, where separate communities now meet in a safe space - physically embodies a viable "third space" and may offer a model for other divided societies. Claiming a part of Nicosia considered as "dead" and transforming it into a forum of contact and unconstrained, decentered dialogue between all communities means to question those normalization narratives implicit to nationalist histories, as well as claims tied to states of exception and division in Cyprus (Makriyianni \& Psaltis, 2007). It means to acknowledge the needs and fears of all communities, and to interrogate dominant narratives of victimization through research. Intergroup contact is instrumental in overcoming conflict as it facilitates the decrease of realistic and symbolic threats, anxiety, and negative stereotypes for the other community (Allport, 1954; Tausch et al., 2010). In the case of the H4C, it is also a unique means of achieving academic excellence in teaching history. Although the $\mathrm{H} 4 \mathrm{C}$ does not have ability to completely overcome systemic states of exception or division, it does offer citizens a safe space to imagine a different Cyprus through transformative knowledge.

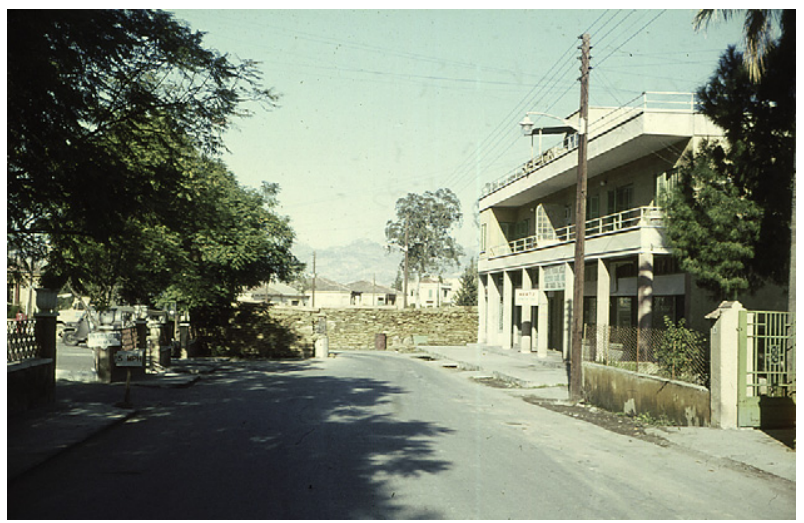

Fig. 6. Barricade in the "no man's land": Nicosia, Cyprus, 1964. Photo courtesy of Sten Boye Poulsen. 


\section{Cracks in the wall: the peace-lines of Belfast, Northern Ireland}

\section{Lorraine Dowler}

"Only the Irish can build a wall of this great size and put a door in it!" This was a customary anecdote of Tom Hartley, a Sinn Fein councilor, historian and later Lord Mayor of Belfast, as he guided political tours of the peace walls along the Falls Road in West Belfast (August 2005 tour). Hartley, in his good-humored way, excavated spaces of commonality or cracks between what had mostly been viewed as two divided rival communities: Irish Catholics and British Protestants. Keeping Hartley's words in mind, I propose that political walls not only divide: in the case of Belfast they are selectively permeable, forming a borderland, not only for former enemies but also for political tourists, not only from across the world but from within the city.

Due to international interest in the peace process, formal tourism has been on the rise in Northern Ireland, leading to the development of rival tourism initiatives by both the state and local communities, with each offering their explanation(s) for the conflict. As was the case when barriers in West Belfast were first built, both the Catholics and the British government are once again drawing "parallel lines" in the sand; however the battle is not so much a question of the legitimacy of the opposing force's ability to protect this area, it is now about controlling tourist representations of the conflict. What seems critical to the West Belfast tourism initiative is that the conflict remains intact in the symbolic realm, with peace lines standing as cultural traces of Irish resistance to the British State. In the context of the borderlands of West Belfast, both new and old doors seem to remain ajar in these supposedly solid political walls allowing for a variety of interactions across these divides.

The building of walls in Northern Ireland does not easily fit representations by the popular media that depict walls as spectacular statements of power struggles between nations. The proliferation of peace walls can be read as symptoms of what Brown (2010) calls "waning sovereignty," under which local communities challenge notions of dominion in ways that are representative of multiple and individualizing political discourses. Brown's argument points to an irony, whereby the building of spectacular political divides on the landscape might at first glance represent the supremacy of the state in its ability to restrain the movement of certain groups. Still, as Brown suggests, these very same walls indicate the vulnerability of the state as they represent "dubiousness, or instability at the core of what they aim to express-qualities that are themselves antithetical to sovereignty and thus elements of its undoing" (24).

The walls of Belfast to some extent challenge Brown's line of reasoning as they represent a more nuanced understanding of place-driven understandings of sovereignty. First, the construction of the first peace-line in Belfast in 1969 was in direct opposition to the erection of state walls. The first peace-line not only controlled the movement of Protestant vigilante groups but also the movement of the state, both physically, in terms of who would have access to the Catholic areas, and politically, in terms of agency for the Irish Catholic community in West Belfast. Second, unlike Brown's interpretations of the more recent erections of walls in Israel, Mexico, Morocco, and Mozambique, in Belfast the state is one of several actors that participate in localized power struggles with a democratic government that argues it "protects" its minority population by controlling mobility in and out of the area. Third, walls not only divide; they are also discriminatingly porous. Walls are part of a larger borderlands defined by the shared cultural, economic, and political contexts of an area. The concept of the borderland transcends rigid notions of cartographic borders, cultural markers, or physical divides (Kaplan \& Häkli, 2002; Sahlins, 1989). In the case of Northern Ireland, Nagle (2009) promotes "exploiting the cracks" in the borderlands whereby a marginalized ethnic group can utilize "partial openings" to challenge government's self-representation as democratic (p. 135).

At first glance, the presence of the peace line performs national allegiances between two rival neighborhoods. Such markers of territoriality - walls, political murals, festivals, and marches - are easy photo opportunities for journalists who contribute to the production of such spectacles. However, even a brief history of the peace lines and temporary barriers indicates the complex nature of the nation building process that is continually complicated by issues of gender, ethnicity, class, race, and sexuality.

In the late summer of 1969 the British Army moved against Catholic and Protestant vigilante groups that were terrorizing areas of Belfast. The army was called in after communal violence had claimed a number of lives in the area. They occupied strategic positions of the Falls Road Area (Catholic stronghold) and immediately began erecting barbed wire fences separating the opposing communities (Lee, 1969). Little did these soldiers know that this temporary divide would give birth to a new type of "barrier design", a design that would later be promoted by urban planners as providing safety through separation, which is comparable to what Pullan writes in her Intervention.

Unfortunately, this first divide would be the beginning of decades of isolation and self-governing for this Catholic community. By October 1969 Belfast had become a divided city, with the Catholic community ensconced within its own self-made barricades that sealed-off more than 90 small streets where Catholic families feared an attack by Protestant forces (Special to the New York Times, 1969). Eventually the Catholic barriers yielded to the state barrier as General Freeland pronounced to an international audience: "The peace line will be a very, very temporary affair. We will not have a Berlin Wall or anything like that in this city" (Harding, 2004). Yet the walls of Belfast remain standing more than 40 years later. There are officially 84 peace lines in Northern Ireland separating Catholic from Protestant communities and 42 of these partitions are scattered in the West, North and South of Belfast City. Many of these barriers were recently refortified and it is estimated that the numbers of barriers have tripled since the signing of the 1994 ceasefire (Geoghegan, 2010).

Groups situated on different sides of a divide often mirror each other due to the shared militarized politics of the common borderlands (Minghi, 2002). Despite the presence of the peace walls, West Belfast can be considered a borderland constituted by everyday expressions of commonality. An obvious case of the political penetrability of these walls was through the Nobel Peace Prize, awarded in 1976 to Betty Williams, a Protestant, and Mairead Corrigan, a Catholic, who both organized peace demonstrations that brought together Catholics and Protestants to protest violent acts by British soldiers, the IRA, and Protestant paramilitary groups. Other less celebrated examples of the permeability of this divide originate in the gendered politics common to both communities. Historically, in West Belfast, women, at least in the popular imagination, were associated more with the home than politics. Accordingly they enjoyed a greater spatial mobility that allowed them to cross these divides to visit the shops on the Shankill Road or the medical clinic. As Tom Hartley would quip to tourists, "the doors in these walls allow the grannies to do their messages" (August 2005 tour). In contrast, (male) taxi drivers were considered the wildmen of West Belfast and tainted as bad nationalists because they continually crossed the peace lines of West Belfast, often shuffling a younger generation of residents who were courting across the religious divide. These two respective groups, however, would not be considered political subjects to a global theater, as would the IRA volunteer, the Protestant paramilitary, or the 
British soldier, and yet these individuals not only destabilized the boundary lines of West Belfast, but also those of a nation viewed by a global audience as the embodiment of an intractable conflict. Many of the women who once crossed over the peace line now shop in new stores in the city center and several of the men who were critical of taxi drivers for crossing the peace lines more than ten years ago have since become taxi drivers themselves, even offering specialized tours for those travelers who want to see the "hot spots" of West Belfast including the peace line (Dowler, 2001).

Although the peace lines as dividing barriers have grown - in number, height and breadth - more recently, they also provide the material framing for a local community festival in the Irish Nationalist area of West Belfast. Established in 1988, the Féile an Phobail, known locally as "the people's festival", was a direct response to the local media's designation of this area as a "terrorist community" (O'Hare, 2009). The residents felt this portrayal was more restrictive than the physical walls that cordoned them off, and they organized a celebration of their community's creativity, energy, and passion for the arts. Féile an Phobail has grown into one of the largest community festivals in Europe and provides a platform for the people of West Belfast to literally tell their "war stories". The festival's organization, exchanges, story-telling, and responses offer residents a political dialogue within the Irish Nationalist community, with other Belfast communities, and with the international community. In this case, the walls of Belfast not only represent a divided past, but also a new means of political expression.

Local stores carry books featuring arty black and white images of the various peace lines for tourists to put on their coffee tables back home. The political murals that once promoted the IRA and antiBritish sentiment are fewer in number, as murals now encourage international solidarity by variously highlighting the victimization of the Palestinians, promoting Basque separatism, or denouncing international tyranny, such as the mural of former President George W. Bush siphoning oil out of Iraq; these are showcased on a section of the Peace Line now referred to as the "International Wall". Whereas the local tourism initiative in West Belfast reproduces the territoriality of the peace line to make a profit, it also has potential to build cross-line relationships. Illustrative of such cooperation is a tour run by a former Catholic prisoners group. The tour guide, a former prisoner and IRA volunteer, walks tourists up and down the Falls Road, explaining the history behind the murals and telling personal stories of life in prison. The tour often consists of Europeans, Americans, and Australians. With middle-class Protestant British couples, he tells stories of life in Long Kesh Prison and IRA missions, punctuating explanations for his actions with phrases such as "it was the times", or explaining how he once refused a mission, breaking ranks with the IRA, because it was potentially too dangerous to bystanders, including Protestants. The tour also includes "a pint" at a local Irish pub with the guide. This guide seeks approval by tourists by presenting himself as an individual, with the agency to make ethical decisions, but, more importantly, he wants to create West Belfast as a welcoming place for middle-class Protestants.

The guide walks some tourists across the divide and drops them off on the Shankill Road with a former UVF volunteer and the tour continues. It seems unfathomable that a former prisoner would feel comfortable crossing the peace line, but as he explained, "it is ok when you are with the tourists but under no circumstances would I walk over there alone" (August 2010 interview). He then smiled and stated, "you know the IRA tour is so much better than the UVF's", adding, "at least that is what the tourists have been telling us". In this new borderlands, communities, rather than the state, now vie for control of the symbolic landscape.

\section{Acknowledgments}

Wendy Pullan's work forms part of the research project "Conflict in Cities and the Contested State" (RES-060-25-0015), supported by the Large Grants Programme of the UK Economic and Social Research Council (ESRC). Karen Till's work was supported in part by The Netherlands Institute for Advanced Study in the Humanities and Social Sciences (NIAS).

\section{References}

Ackleson, J. (1999). Metaphors and community on the US-Mexican border: identity, exclusion, inclusion and operation hold the line. Geopolitics, 4, 155-179.

ACLU (American Civil Liberties Union). (2008). Fact sheet on U.S. 'constitution free zone'. http://www.aclu.org/technology-and-liberty/fact-sheet-us-constitutionfree-zone Accessed October 2011.

Allport, G. (1954). The nature of prejudice. Boston: Beacon Press.

Amoore, L. (2011). On the line: writing the geography of the virtual border. Political Geography, 30, 63-64.

Anzaldúa, G. (1987). Borderlands/La Frontera: The new mestiza. San Francisco: Aunt Lute Books.

Arieli, S. (2008). Mevaseret Adumim (E-1): A road to nowhere. www.annaveeder. files.wordpress.com/2009/03/2008-12_mevaseret_adumim.pps Accessed November 2011.

Azoulay, A. (October 14 2011). Infra-destructure. Paper delivered at the 'injured cities/urban afterlives' conference at the Center for Critical Analysis of Social Difference. New York: Columbia University.

Bar-Tal, D., \& Teichman, Y. (2005). Stereotypes and prejudice in conflict: Representations of Arabs in Israeli Jewish society. Cambridge: Cambridge University Press.

Billig, M. (1995). Banal nationalism. London: Sage Publications.

Bowers, K. (2010). Saying what the law isn't: legislative delegations of waiver authority in environmental laws. Harvard Environmental Law Review, 34 257-310.

Broome, B. J. (1998). Overview of conflict resolution activities in Cyprus: their contribution to the peace process. The Cyprus Review, 10, 55

Brown, W. (2010). Walled states, waning sovereignty. Cambridge: Zone Books.

Butler, J. (2006). Indefinite detention. In Precarious life: The powers of mourning and violence (2nd ed.) (pp. 50-100). London and New York: Verso.

Constantinou, C. (2008). On the Cypriot states of exception. International Political Sociology, 2, 145-164.

Cortez, R. (January 13 2008). Build bridges, not barriers. Pittsburgh Tribune-Review. Demetriou, O. (2007). To cross or not to cross? Subjectivization and the absent state in Cyprus. Journal of the Royal Anthropological Institute, 13, 987-1006.

Dolphin, R. (2006). The West Bank wall: Unmaking Palestine. London and Ann Arbor: Pluto Press.

Dowler, L. (2001). No man's land: gender and the geopolitics of mobility in West Belfast, Northern Ireland. Geopolitics, 6(3), 158-176.

Dumper, M., \& Pullan, W. (February 2010). The cost of failure. Chatham house briefing paper. London: Chatham House. www.chathamhouse.org.uk/publications/ papers/view/-/id/835/ Accessed November 2011.

Epaminondas, M. (2011). Home for cooperation. Nicosia: AHDR.

Foundation for Middle East Peace. (2002). Sharon's new map: Report on Israeli settlement in the occupied territories. 12(3 May-June). www.fmep.org/reports/ archive/vol.-12/no.-3/sharons-new-map Accessed November 2011.

Geoghegan, P. (2010). A difficult difference: Race, religion and the new Northern Ireland. Dublin: Irish Academic Press.

Gregory, D. (2006). The black flag: Guantánamo Bay and the space of exception. Geografiska Annaler, 88, 405-427.

Gregory, D. (2009). Vanishing points: law, violence, and exception in the global war prison. In E. Boehmer, \& S. Morton (Eds.), Terror and the postcolonial (pp. 5598). Oxford: Wiley-Blackwell.

Hadjipavlou-Trigeorgis, M. (1993). Unofficial intercommunal contacts and their contribution to peacebuilding in conflict societies: the case of Cyprus. The Cyprus Review, 5, 68-87.

Harding, T. (February 25 2004). The security wall at our doorstep. The Telegraph. http://www.telegraph.co.uk/news/uknews/1455245/The-security-wall-on-our doorstep.html Accessed December 2011.

Hocknell, P. R. (2001). Boundaries of cooperation: Cyprus, de facto partition, and the delimitations of transboundary resource management. London: Kluwer Law International.

Israel Ministry of Defense. (2012). Israel's security fence. www.seamzone.mod.gov.il/ Pages/ENG/operational.htm Accessed January 2012.

Johnson, C., Jones, R., Paasi, A., Amoore, L., Mountz, A., Salter, M., et al. (2011). Interventions on rethinking 'the border' in border studies. Political Geography, $30,61-69$.

Jones, R. (2009). Agents of exception: border security and the marginalization of Muslims in India. Environment and Planning D: Society and Space, 27, 879-897.

Jones, R. (2012). Spaces of refusal: rethinking sovereign power and resistance at the border. Annals of the Association of American Geographers, 102, 685-699.

Kaplan, D. H., \& Häkli, J. (2002). Boundaries and place: European borderlands in geographical context. Lanham: Rowman and Littlefield. 
Kriesberg, L. (1998). Intractable conflict. In E. Weiner (Ed.), The handbook of interethnic coexistence (pp. 182-198). New York: Continuum.

Kroyanker, D. (1982). Jerusalem: Planning and development 1979-82. Jerusalem: Jerusalem Institute for Israel Studies.

Lee, J. (16 August 1969). British soldiers in Belfast move against rioters. New York Times. http://www.telegraph.co.uk/news/uknews/1455245/The-security-wallon-our-doorstep.html Accessed December 2011.

Lein, Y. (2004). Forbidden roads: The discriminatory West Bank road regime. Jerusalem: B'Tselem: The Israeli Information Center for Human Rights in the Occupied Territories.

Loizos, P. (2006). Bicommunal initiatives and their contribution to improved relations between Turkish and Greek Cypriots. South European Society and Politics, 11(1), 179-194.

Lytras, E., \& Psaltis, C. (2011). Formerly mixed villages in Cyprus: Representations of the past, present and future. Nicosia: AHDR.

Makriyianni, C. \& Onurkan Samani, M. (2011). Inauguration speech for the home for cooperation in Nicosia, Cyprus (11 May). Speech available from AHDR

Makriyianni, C., \& Psaltis, C. (2007). The teaching of history and reconciliation. The Cyprus Review, 19, 43-69.

McLemore, D. (July 2 2007). Fence plans have border residents hopping mad. The Wenatchee World. http://www.wenatcheeworld.com/news/2007/jul/02/fenceplans-have-border-residents-hopping-mad Accessed 13.07.12.

Meinhof, U. (2002). Living (with) borders: Identity discourses on East-West borders in Europe. Aldershot: Ashgate.

Minghi, J. (2002). Changing geographies of scale and hierarchy in European borderlands. In D. H. Kaplan, \& J. Häkli (Eds.), Boundaries and place: European borderlands in geographical context (pp. 34-49). Lanham: Rowman and Littlefield.

Mountz, A. (2011). Border politics: spatial provision and geographical precision. Political Geography, 30, 65-66.

Nagle, J. (2009). The right to Belfast city centre: from ethnocracy to liberal multiculturalism? Political Geography, 28, 132-141.

Newman, D. (2006). The lines that continue to separate us: borders in our 'borderless' world. Progress in Human Geography, 30, 143-161.

No Border Wall. (n.d.). http://www.notexasborderwall.com Accessed October 2011.

Osborne, J. (May 1 2007). DHS: 135 miles of fence going up in Texas. The Monitor

O'Hare, M. (February 2009). Féile an Phobail: Twenty years on. Documentary film. Belfast/Northern Ireland: Sonas Productions/Aired on British Broadcasting Company.

Paasi, A. (1996). Territories, boundaries, and consciousness: The changing geographies of the Finnish-Russian boundary. New York: J. Wiley \& Sons.

Paasi, A. (2011). Borders, theory and the challenge of relational thinking. Political Geography, 30, 62-63.

Papadakis, Y. (2008). Narrative, memory and history education in divided Cyprus. A comparison of schoolbooks on the 'history of Cyprus'. History E Memory, 20, $128-148$.

Psaltis, C. (2011). Intergroup trust and contact in transition: a social representations perspective on the Cyprus conflict. In I. Markova, \& A. Gillespie (Eds.), Trust and conflict: Representations, culture and dialogue (pp. 83-104). London: Routledge.
Psaltis, C., Duveen, G., \& Perret-Clermont, A. N. (2009). The social and the psychological: structure and context in intellectual development. Human Development, 52, 291-312.

Psaltis, C., Lytras, E., \& Costache, S. (2011). History educators across the existing divide in Cyprus: Perceptions, beliefs and practices. Nicosia: AHDR.

Pullan, W. (2007). Contested mobilities and the spatial topography of Jerusalem. In L. Purbrick, J. Aulich, \& G. Dawson (Eds.), Contested spaces: Cultural representations and histories of conflict (pp. 49-73). London: Palgrave Macmillan.

Sahlins, P. (1989). Boundaries: The making of France and Spain in the Pyrenees. Berkeley: University of California Press.

Segev, T. (2007). 1967: Israel, the war and the year that transformed the Middle East New York: Metropolitan Books, Henry Holt and Company.

Sieff, K. (April 29 2008). Border fencing. The Brownsville Herald. http://www. brownsvilleherald.com/news/border-86233-button-hot.html Accessed October 2011.

Silberman, M., Till, K. E., \& Ward, J. (Eds.), (2012). Walls, borders, and boundaries: Spatial and cultural practices in Europe. Oxford \& New York: Berghahn.

Sklair, L. (2011). Iconic architecture and urban, national and global identities. In D. E. Davis, \& N. Libertun de Duren (Eds.), Cities and sovereignty. Identity politics in urban spaces (pp. 79-95). Bloomington: Indiana University Press.

Special to the New York Times. (10 September 1969). Barriers will go up, Ulster chief says: Chichester-Clark pledges 'peace line' in Belfast. http://select.nytimes.com/gst/ abstract.html? res =F40E16FC3B551B7B93C2A81782D85F4D8685F9\&scp $=1 \&$ $\mathrm{sq}=$ September $+10 \% 2 \mathrm{C}+1969 \% 2 \mathrm{C}+$ Northern + Ireland\&st $=\mathrm{p}$ Accessed December 2011

Tausch, N., Hewstone, M., Kenworthy, J., Psaltis, C., Schmid, K., Popan, J., et al. (2010). Secondary transfer effects of intergroup contact: alternative accounts and underlying processes. Journal of Personality E Social Psychology, 99, 282-302.

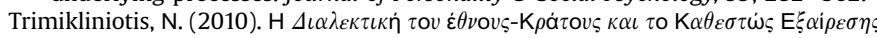
[The nation-state dialectic and the state of exception]. Athens: Savalas.

UNFICYP (U.N. Peacekeeping Force in Cyprus). (2012). History: Background. http:/ www.unficyp.org/nqcontent.cfm?a_id=1600\&tt=graphic\&lang=11 Accessed January 2012.

USDHS (U.S. Department of Homeland Security). (2008). Statement of Secretary Michael Chertoff regarding exercise of waiver authority. Washington, D.C: DHS http://www.dhs.gov/xnews/releases/pr_1207083685391.shtm Accessed October 2011.

USHRCJ (U.S. House of Representatives Committee on the Judiciary). (2005) Sensenbrenner praises real id act's inclusion in supplemental conference report Press release (May 4).

USHRCR (U.S. House of Representatives Congressional Record). (February 9 2005). H459. (Statement of representative Sheila Jackson-Lee).

Whitaker, T. (February 22 2007). Border mayors voice concerns over wall but see progress from Washington. The Monitor.

World Bank. (2007). Movement and access restrictions in the West Bank: Uncertainty and inefficiency in the Palestinian economy. www.siteresources.worldbank.org/ INTWESTBANKGAZA/Resources/WestBankrestrictions9Mayfinal Accessed November 2011.

Zertal, I., \& Eldar, A. (2007). Lords of the land: The war over Israel's settlements in the occupied territories, 1967-2007. V. Eden (Trans). New York: Nation Books. 